\title{
Cultured heart cells from oyster: an experimental approach for evaluation of the toxicity of the marine pollutant tributyltin
}

\author{
Mickaël DrogueT ${ }^{1, a}$, Nicole Devauchelle ${ }^{2}$, Jean-Pierre PenNec, Brian QuINN ${ }^{3}$ \\ and Germaine DORANGE ${ }^{1}$ \\ 1 EA 1274 M2S, Facteurs nerveux et Structuration tissulaire, UFR Médecine et Sciences de la Santé, 22 avenue Camille Desmoulins, \\ 29238 Brest Cedex, France \\ 2 IFREMER, Centre de Brest, BP 70, 29280 Plouzané Cedex, France \\ 3 Irish Centre for Environmental Toxicology, Galway-Mayo Institute of Technology, Dublin Rd, Galway, Ireland
}

Received 20 March 2012; Accepted 1st June 2012

\begin{abstract}
European Community regulations on chemicals promote alternative methods to test substances presenting potential risks for the environment. In the present work, cultured atrial cells isolated from oyster (Crassostrea gigas) were used as an experimental model to investigate the toxicity of tributyltin (TBT) after short-time exposure at concentrations representative of those that can be measured in seawater, marine sediments and/or bivalves bioaccumulating this pollutant. In vitro and in vivo assays produce values of the same order of magnitude for both animal/cell survival and heart/cardiomyocyte beating rate. The survival rate of whole animals decreased from $10^{-6} \mathrm{M}$ TBT after 3 days. For cultured cells, the viability, evaluated using 3-(4, 5-dimethylthiazolyl-2)-2, 5-diphenyltetrazolium bromide (MTT) assay, significantly decreased after two days of treatment with $10^{-6} \mathrm{M} T B T$, and after six days with $10^{-10} \mathrm{M} T B T$. The percentage of apoptotic cells, quantified by flow cytometry and YO-PRO ${ }^{\circledR}-1$ iodide, a nucleic acid stain that only permeates cells that are beginning to undergo apoptosis, increased significantly in these cases. Moreover, intracellular concentration of $\mathrm{Ca}^{++}$had increased after $10 \mathrm{~min}$ of exposition to $10^{-6} \mathrm{M}$, and could be associated with apoptotic processes. As patch clamp experiments showed that $\mathrm{Ca}^{++}$conductance was decreased, intracellular calcium increase could mainly be due to a release from internal stores. The decreases in beating rhythm could be explained by the decrease in adenosine triphosphate (ATP) production revealed by ${ }^{31} \mathrm{P}$ nuclear magnetic resonance (NMR) spectroscopy and confirmed by the increase of the $\mathrm{K}_{\mathrm{ATP}}$ channel conductance. The related hyperpolarization and the disturbances of the energetic metabolism were clearly related to the loss of the atrial cell contractility and viability.
\end{abstract}

Keywords: Oyster / Heart cells / Flow cytometry / Tributyltin / Toxicity / Antifouling

\section{Introduction}

In vitro models provide useful systems to assess cytotoxicity and genotoxicity of chemicals and to understand the mechanisms of chemically-induced injury. While numerous cell cultures have been developed in vertebrates and insects, attempts in marine invertebrates have not resulted in the development of cell lines. However, functional primary cultures have been frequently established using heart cells of bivalves (e.g., Le Marrec-Croq et al. 1999; Pennec et al. 2002, 2004; Talarmin et al. 2008; Hanana 2011), especially the oyster Crassostrea gigas. Such cell cultures can be obtained from freshly isolated or cryopreserved cells (Pennec et al. 2004) using a freeze/thaw protocol defined in the scallop Pecten maximus by Le Marrec-Croq et al. (1998) that was optimised in C. gigas by Droguet (2006), thus providing a constant standardized source of cells for applied research.

a Corresponding author: mickael.droguet@univ-brest.fr
Toxicological studies have been already carried out using C. gigas heart cells in primary cultures as experimental models (Burgeot et al. 1995; Domart-Coulon et al. 2000; Pennec et al. 2002; Hanana et al. 2011). However, this model is not yet validated as a standard method for ecotoxicological evaluations.

Among marine pollutants, organotins, such as $T B T$, are highly toxic to a wide range of organisms (Inoue et al. 2006a, 2006b; Ohji et al. 2005; Antizar-Ladislao 2008). The use of TBT in antifouling paints has been prohibited since 2008 (IMO, International Maritime Organization, www.imo.org). However, TBT and its degradation products, dibutyltin and monobutyltin, can remain in marine sediments for years (Pelletier et al. 2006). Reduction in the levels of TBT in harbours is expected to be slow since this compound is quite stable, particularly in anoxic sediments (Burton et al. 2004; Berto et al. 2007). The half-life of $T B T$ in anaerobic conditions is about many years (Dowson et al. 1993). Anoxic sediments are therefore a reservoir of $T B T$, which can be re-solubilized in 
the water column by desorptive processes (Unger et al. 1988; Le Deuff et al. 1994). In the present paper, TBT was chosen because it is on the list of the OSPAR convention (OSlo/PAR is a convention for the protection of the marine environment of the North-East Atlantic, 2004) as one of the chemicals for priority action in marine ecosystems. Pathological effects of TBT have been largely demonstrated and the implementation of the OSPAR convention on living marine animals requires a system for its regular monitoring and inspection.

Bivalve molluscs were the first taxonomic group to exhibit morphological, reproductive and growth damage in response to TBT contamination (Alzieu 1991). In aquatic animals, $T B T$ is known to induce the development of male sex characteristics in females, particularly in several gastropods (Hagger et al. 2006; Horiguchi 2006; Horiguchi et al. 2006; Janer et al. 2006; Viglino et al. 2006), thus causing sterility. It also makes aquatic animals more vulnerable to infectious diseases (Anderson et al. 1996) and has deleterious effects on oyster growth and reproduction (Alzieu 1991; Gagné et al. 2003; Inoue et al. 2004, 2006a, 2006b, 2007). Human exposure may arise from consumption of $T B T$-contaminated food products (Jurkeviewicz et al. 2004). This biocide, known for its immunotoxicity, hepatotoxicity and neurotoxicity (Dong et al. 2006; Tsunoda et al. 2006), has also been shown to be a mitochondrial toxin (Jurkeviewicz et al. 2004) and affects many cellular mechanisms, leading to apoptosis (Jurkeviewicz et al. 2004; Cima et al. 2008; Châtel et al. 2011; Zhang et al. 2011).

The present study was designed to evaluate the toxicity of low concentrations of TBT in cultured $C$. gigas cardiac cells in order to validate this model as a useful tool to assess the risks caused by chemicals in the marine environment. With this objective, mortality, cytotoxic and apoptotic effects, intracellular free $\mathrm{Ca}^{++}$, ATP level, spontaneous cardiac beating rhythm and electrophysiological properties of the cell membrane were studied to evaluate $T B T$ toxicity.

\section{Materials and methods}

\subsection{Chemical}

The toxic potential of organotins for various organisms is well documented. However, TBT concentrations reported in the literature for $T B T C l$ (Tributyltin chloride) or TBTO (Tributyltin oxide) are expressed in $\mathrm{ng} \mathrm{L}^{-1}$ or $\mathrm{nM} \mathrm{L}^{-1} \mathrm{Sn}$ or tin. In the present work, we chose to expose animals and cultured heart cells to $\mathrm{TBTCl}$ (99\% purity; Sigma-Aldrich (T50202) in vivo and in vitro. We tested concentrations from $10^{-4} \mathrm{M}\left(29.1 \mathrm{mg} \mathrm{L}^{-1} \mathrm{TBT}\right.$ and $\left.11.87 \mathrm{mg} \mathrm{L}^{-1} \mathrm{Sn}\right)$ to $10^{-12} \mathrm{M}$ (0.291 ng L $\mathrm{L}^{-1}$ TBT and $0.118 \mathrm{ng} \mathrm{L}^{-1} \mathrm{Sn}$ ), which are environmentally realistic. Since the ban of the use of TBT in antifouling paints, $100 \mathrm{ng} \mathrm{L}^{-1}$ of $T B T$ (expressed as $\mathrm{Sn}$ ), which corresponds to a concentration of about $10^{-9} \mathrm{M}$, has been measured in the water column (Bhosle et al. 2004; AntizarLadislao 2008).

TBT chloride (stock solution $10^{-2} \mathrm{M}$ ) was prepared in dimethyl sulfoxide $\left(D M S O<1 \%\right.$ ) and stored at $4{ }^{\circ} \mathrm{C}$, in the dark. Freshly prepared solutions of TBT $\left(10^{-4} \mathrm{M}\right.$, $10^{-6} \mathrm{M}, 10^{-8} \mathrm{M}, 10^{-9} \mathrm{M}, 10^{-10} \mathrm{M}$ and $10^{-12} \mathrm{M}$ ) were diluted in sterile sea water (SSW) for animal exposure and in the culture medium for cell exposure. Concentrations ranging from $10^{-4} \mathrm{M}$ to $10^{-12} \mathrm{M}$ were first tested to evaluate the cell viability and the beating rhythm in vivo/in vitro. Then, depending on results obtained from these tests, only some concentrations of $T B T$ were tested for the other analytical methods aimed at trying to explain mechanisms of $T B T$ toxicity. The effects of $10^{-6} \mathrm{M} T B T$ were systematically evaluated; lower and/or higher concentrations were also tested, depending on exposure times and sensitivity of the analytical methods. The absence of DMSO toxicity at $1 \%$ o (v/v) had been previously tested. For electrophysiological studies, channel blockers were dissolved in SSW and added to the culture medium at a final concentration stated in the results section: verapamil $10^{-6} \mathrm{M}$ (Sigma V4629); TEA $10^{-3} \mathrm{M}$ (Sigma T2265); charybdotoxin $10^{-6} \mathrm{M}$ (Sigma C7802); glibenclamide $10^{-4} \mathrm{M}$ (Sigma C0639); clotrimazol $10^{-4}$ M (Sigma C6019).

\subsection{In vivo TBT exposure; analysis of cardiac rhythm and animal survival}

Adult oysters obtained from a local shellfish farm were washed with SSW and stored for one week before experimentation in lab tanks filled with circulating aerated SSW, in a room where temperature was regulated at $18{ }^{\circ} \mathrm{C}$. A mixture

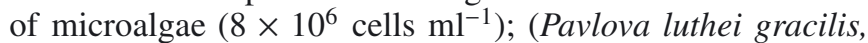
Chaetoceros, Skeletonema costatum, Isochrisis galbana) was added to the SSW each day. To measure cardiac rhythm, a hole was drilled through the right valve of the animals, above the pericardium (10 animals per batch).

$T B T$ was diluted in SSW to give final concentrations from $10^{-3}$ to $10^{-12} \mathrm{M}$. Ten oysters per batch were exposed to each concentration of $T B T$.

The percentage of dead oysters was evaluated daily over a period of 11 days.

Before evaluation of heart beating rate, each animal was removed from the tank and placed under a microscope for $10 \mathrm{~min}$ to reduce the impact of stress on cardiac contractions. Heart contractions were counted 6 times over $1 \mathrm{~min}$ for each oyster after 6 days of TBT exposure.

\subsection{Ex vivo studies}

The hearts of animals exposed to $T B T$ and those of nonexposed controls were taken out in order to obtain ${ }^{31} \mathrm{P}$ nuclear magnetic resonance (NMR) spectra. Analyses were performed at $15^{\circ} \mathrm{C}$ using a Bruker DRX Avance 500 spectrometer $(\Phi=$ $5 \mathrm{~mm}$ inverse triple-resonance high resolution probe Bruker TBI $1 \mathrm{H}$ \{BB \#33 $\} 13 \mathrm{C}$ ). Six hearts were pooled for each treatment: controls and oysters exposed for $10 \mathrm{~min}$ to $T B T$ concentrations ranging from $10^{-6} \mathrm{M}$ to $10^{-10} \mathrm{M}$ in $\mathrm{D}_{2} \mathrm{O}$ (1 $\left.100 \mathrm{mosm}\right)$. Diphosphonate methylen acid (DPMA) $4 \mathrm{mM}$, solubilized in $\mathrm{D}_{2} \mathrm{O}$, was used as an internal standard.

\subsection{In vitro analyses}

\subsubsection{Oyster atrial cell cultures}

Animals were rinsed in $70^{\circ}$ ethanol. They were then opened and the heart was taken out in a sterile atmosphere and 
treated with antibiotics $4 \mathrm{X}, 2 \mathrm{X}, \mathrm{X}$ (X: $2 \mathrm{~g} \mathrm{~L}^{-1}$ erythromycin; $13 \mathrm{~g} \mathrm{~L}^{-1}$ streptomycin,; $4 \mathrm{~g} \mathrm{~L}^{-1}$ gentamicin). The atria were dissected, ground into pieces of approximately $1 \mathrm{~mm}^{3}$ and suspended in pronase $0.0125 \%$ in Hank's balanced salt solution (w/v) for $12 \mathrm{~h}$ at $4{ }^{\circ} \mathrm{C}$ for cell dissociation, according to the protocol described for scallop by Le Marrec-Croq et al. (1999). Isolated cells were filtered through a 60- $\mu \mathrm{m}$ nylon mesh and centrifuged (300 $\mathrm{g}$ for $5 \mathrm{~min}$ ). The pellet was washed twice with SSW. Cell viability, evaluated by the trypan blue exclusion test, was $95 \%$ or more. Cells were resuspended in culture medium (SSW with 10\% Leibovitz L-15; 10 mM Hepes buffer; $10 \%$ foetal calf serum; antibiotics X; $\mathrm{pH}$ $7.3 ; 1100 \mathrm{mOsm})$. Then, $4 \times 10^{5}$ cells were inoculated into in $200 \mu \mathrm{l}$ of culture medium per well in 96-well plates in order to investigate $T B T$ effect on cell viability. For electrophysiological studies and the evaluation of $T B T$ effect on (i) spontaneous beating rhythm and (ii) intracellular free $\mathrm{Ca}^{++}$level into cardiomyocytes, $8 \times 10^{6}$ cells in $2 \mathrm{ml}$ of culture medium were seeded into dishes of $35 \mathrm{~mm}$ diameter. The number of atrial cells isolated per oyster was routinely 1 to $1.5 \times 10^{6}$. Cells in culture were incubated at $18{ }^{\circ} \mathrm{C}$. Half of the medium was replaced for the first time 2 days after seeding. Thereafter, the medium was fully replaced every two days.

For flow cytometry analysis, cells were maintained in suspension $\left(10^{5}\right.$ cells $\left.\mathrm{ml}^{-1}\right)$.

\subsubsection{Atrial cell viability}

The MTT assay used to evaluate the cell viability is based upon the ability of mitochondrial succinate dehydrogenase to reduce the yellow 3-(4, 5-dimethylthiazolyl-2)-2, 5diphenyltetrazolium bromide into a blue derivative, formazan. The amount of formazan is quantified by spectrophotometry at $570 \mathrm{~nm}$ (Mosman 1983). This test was used to assess the cytotoxicity of TBT from $10^{-12}$ to $10^{-4} \mathrm{M}$, after 2 and 6 days of incubation at $18{ }^{\circ} \mathrm{C}$. Each assay was repeated 4 times using different cell cultures. Within each assay, each dose-group was replicated 4 times. Results were expressed as a percentage of optical density relative to the control without toxicant.

\subsubsection{Apoptosis and necrosis}

After 10 min of treatment with different concentrations of TBT $\left(10^{-8} \mathrm{M}, 10^{-6} \mathrm{M}\right.$ or $\left.10^{-4} \mathrm{M}\right), 5 \times 10^{5}$ cells per assay were analyzed by flow cytometry to determine the translocation of phosphatidylserine to the outer surface of the cell membrane, using human phospholipid binding protein annexin $\mathrm{V}$ conjugated with fluorescein (Immunotech, K2350). Apoptosis and necrosis were analysed with quadrant statistics on propidium iodide-negative cells, fluorescein isothiocyanate-positive cells, and propidium iodide (PI)-positive cells.

Apoptosis was also assessed by using $1 \mu \mathrm{M}$ of the greenfluorescent YO-PRO ${ }^{\circledR}-1$ stain (YOPRO ${ }_{-1}^{\circledR}$ ) (YP; Molecular Probes - Idziorek et al. 1995). Cells were examined under an Olympus epifluorescence microscope BX-40 (cube U-MWB, excitation filter $450-480 \mathrm{~nm}$, barrier filter $515 \mathrm{~nm}$ ).

\subsubsection{Cardiomyocyte beating rate}

The fibroblastic cells, organized in networks, began to contract spontaneously after 4 days. Beating rate of these cardiomyocytes was evaluated under control conditions and after 6 days of treatment with $T B T$, using an inverted microscope. Measures were repeated 6 times for each cell culture.

\subsubsection{Cardiomyocyte electrophysiological properties}

The macro-patch clamp technique (Pennec et al. 2004) was used to record membrane currents in cultured cardiomyocytes under voltage-clamped conditions in the cell-attached configuration. Pipettes were pulled from borosilicate glass capillaries (GC150 F10; Clark Electromedical, Phymep, Paris, France), using a microprocessor-controlled puller (DMZ, Germany), and they were automatically heat polished. The diameter of the opening $(3 \pm 0.02 \mu \mathrm{m})$ was checked by electron microscopy. The average resistance of pipettes filled with the standard medium (modified SSW) was 1.5 Mohm. Junction potential was corrected before realization of a seal. The tip of the pipette was positioned in contact with the cell membrane using a hydraulic micromanipulator (Narishige, Tokyo, Japan). A moderate suction was then applied to induce the formation of a seal better than 1 Gohm (gigaseal); thereafter, the depression was released. Patches showing either bleb formation or unstable seal values were discarded. The formation of the seal and the capacitance compensation were monitored on an oscilloscope (TDS 340A; Tektronics, USA). Recordings were performed at room temperature (averaging $20{ }^{\circ} \mathrm{C}$ ). The microelectrodes were connected to an amplifier (Geneclamp 500B, Axon, USA) via a headstage designed for voltage measurement (HS-2A; Axon). Current measurements were performed with a patch-clamp amplifier (Geneclamp 500B) equipped with a current-to-voltage converter headstage (CV5 series; Axon). Outputs (voltage and current) were connected to the oscilloscope and a micro-computer (PC-compatible) via an analogue-to-digital interface (Card ref. 6024E, National Instrument, USA). A program (WCP v. 4.05 from Strathclyde University, Scotland, UK) was used to record the currents and to deliver sequences of programmed voltage pulses to the Geneclamp and then to the membrane patch. A classical $\mathrm{P} / 4$ protocol of pulses was used to remove residual leak current (if any) and residual capacitance artefacts (Almers et al. 1983). The currents were further analysed off-line using WCP to calculate ionic conductances. Measurements were performed at room temperature in the culture medium at $\mathrm{pH} 7.3$. Recordings were made 10 min following addition of TBT from $10^{-12} \mathrm{M}$ to $10^{-9} \mathrm{M}$.

\subsubsection{Intracellular free $\mathrm{Ca}^{++}$}

Variations of intracellular calcium rate were measured with the fluorescent dye Fura-2 test (Interchim) according to the method of Grynkiewicz et al. (1985). Intracellular $\mathrm{Ca}^{++}$was determined in adherent cardiac cells. A solution of $2 \mathrm{mM}$ Fura2 AM ester in dimethylsulfoxide (DMSO), was diluted (v/v) in Pluronic ${ }^{\circledR}$ F-127 (Molecular Probes), a non-ionic surfactant 


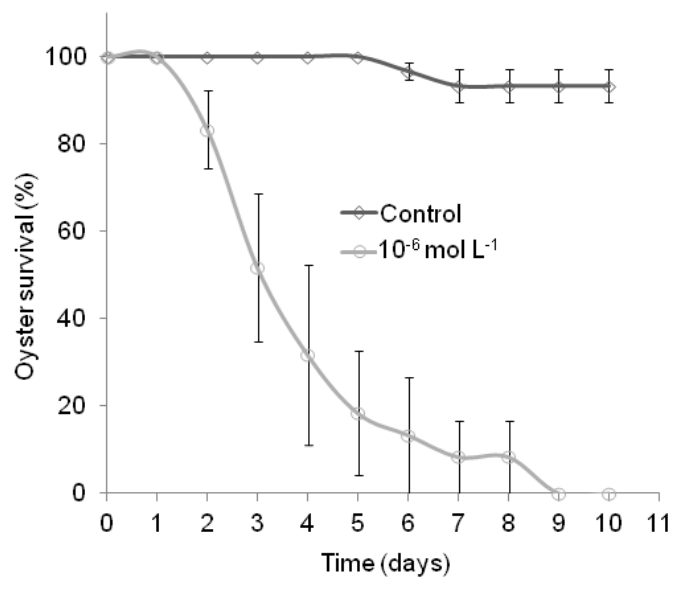

Fig. 1. Oyster survival over an $11 \mathrm{~d}$ period after treatment with $10^{-6} \mathrm{M}$ $T B T$, compared with controls ( $n=4$, with 10 oysters per assay).

polyol (pluronic buffer). This solution was diluted to a concentration of $2 \mu \mathrm{M}$ in PBS $1100 \mathrm{mOsm}$ and was added to the cells. After $1 \mathrm{~h}$ incubation at $18^{\circ} \mathrm{C}$, cells were placed under a fluorescent microscope equipped with the image system processing FLUOSTAR ${ }^{\circledR}$ (IMSTAR Company), adapted to the measurement of Fura-2 AM fluorescence. Intracellular $\mathrm{Ca}^{++}$ was measured to assess the relationship between Fura-2 related to calcium and free Fura-2, measured respectively at $380 \mathrm{~nm}$ and $340 \mathrm{~nm}$. Control intracellular $\mathrm{Ca}^{++}$was measured in cells before $T B T$ exposition.

\subsection{Statistical analysis}

Results were given as mean value \pm SEM. As the number of samples (oysters or cells) in each tested concentration was limited $(n=4-6)$. Normality of data distribution was tested with Shapiro-Wilks tests, which mostly indicated non-normal distributions'. Then, unless specified in figure legends, the comparison between the means was carried out by a non-parametric test (Mann-Whitney). Significant difference was accepted for $p<0.05$.

\section{Results}

\subsection{In vivo oyster survival}

Untreated control oyster survival was higher than $95 \%$ after 11 days. In contrast, TBT $10^{-6} \mathrm{M}$ caused a time-dependant decrease in animal survival after 3 days, with mortality reaching $100 \%$ after 11 days of exposure (Fig. 1).

\subsection{Cultured cells}

Oyster atrial cells were observed under an inverted microscope after 4 days of culture. Three types of isolated cells were attached to the substrate: round cells, fibroblastic cells

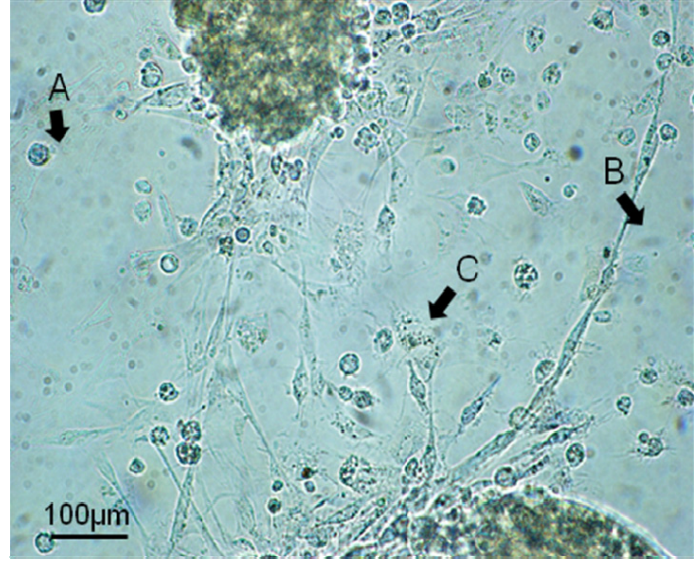

Fig. 2. Oyster atrial cells after 4 days of culture, observed under an inverted microscope; A: round cells, B: cardiomyocytes in a cell network, C: epithelial round cells.

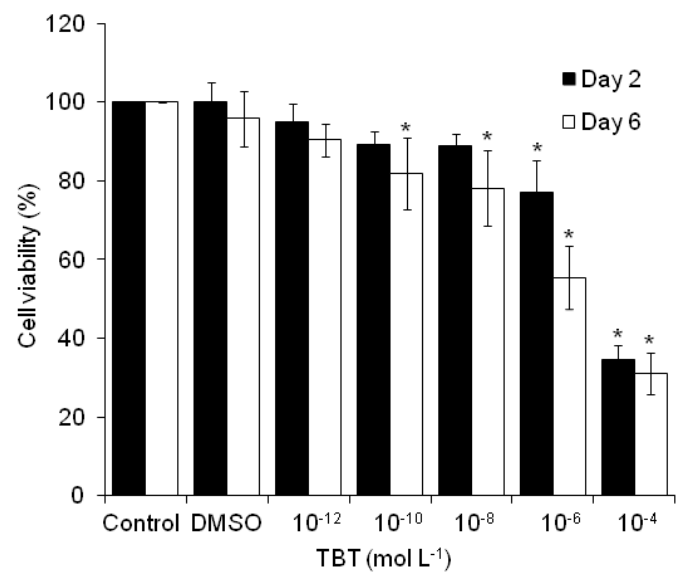

Fig. 3. Viability of cultured atrial cells exposed to $T B T$ for 2 and 6 days; control: untreated cells; DMSO: cells treated with $D M S O$ [1\%o] - MTT assay; *means are significantly different $(p<0.05)$ from control $(n=6)$.

and epithelial-like cells. The presence of numerous cells in aggregates was noted. Networks of spontaneously contractile fibroblastic cells developed between these aggregates (Fig. 2). These contractile fibroblastic cells were cardiomyocytes.

\subsection{Cell viability - Apoptosis}

The MTT reduction assay showed a dose- and timedependent toxicity of TBT for cultured atrial cells (Fig. 3). A significant reduction in cell viability was observed after 6 days of incubation with $10^{-10} \mathrm{M} T B T$, and only two days with $10^{-6} \mathrm{M} T B T$. No significant increase in cell mortality was observed with $10^{-12} \mathrm{M} T B T$ whatever the duration of incubation.

According to the above results, apoptosis and necrosis were studied on cells maintained in suspension to allow analyses using YO-PRO ${ }^{\circledR}-1$ and flow cytometry. Consequently, cells in suspension were exposed for a short incubation period (10 min) to high concentrations of TBT ranging from $10^{-8} \mathrm{M}$ to $10^{-4} \mathrm{M}$. These experimental conditions allowed the study 


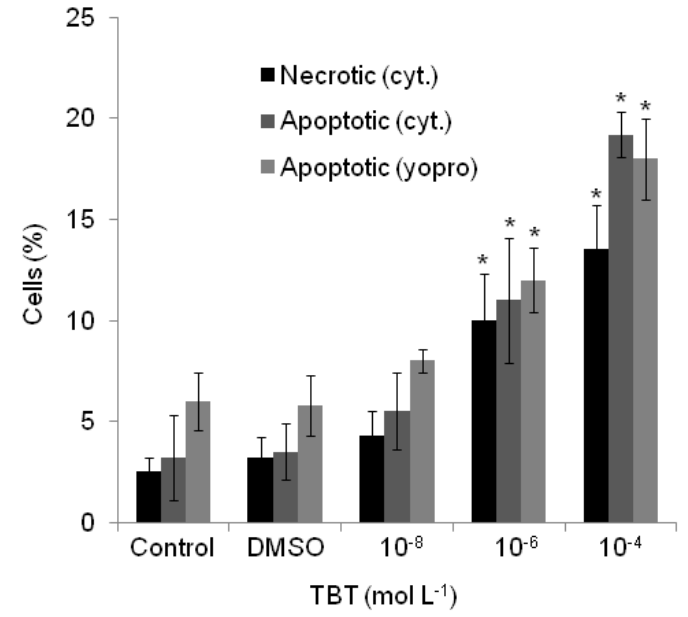

Fig. 4. Induction of apoptosis (flow cytometry or YOPRO ${ }^{\circledR}-1$ staining) and necrosis (flow cytometry) in cultured atrial cells exposed for $10 \mathrm{~min}$ to $T B T$; $\mathrm{C}$ : control; *means are significantly different $(p<0.05)$ from control $(n=4)$.

of the acute toxicity of TBT and to investigate mechanisms of cell death. Experiments revealed a significant increase of both apoptosis and necrosis (Fig. 4) in cells treated with $10^{-6} \mathrm{M}$ and $10^{-4} \mathrm{M} T B T$ for $10 \mathrm{~min}$

\subsection{Cardiac beating rhythm}

In vitro and in vivo, TBT induced a negative chronotropic effect on heart beating rate with concentrations ranging from $10^{-10} \mathrm{M}$ to $10^{-8} \mathrm{M}$ (Fig. 5). It could be seen that cultured cells were more sensitive than oysters by an order of magnitude since a significant effect was observed from $10^{-10} \mathrm{M}$ in cultured cells compared with $10^{-7} \mathrm{M}$ in whole oysters, after 6 days of $T B T$ treatment (Fig. 5b). No effect was observed at concentrations of $T B T$ lower than $10^{-10} \mathrm{M}$ in either experiment. It should be noted that $1 / 1000$ DMSO alone, which was previously checked, had no effect.

\subsection{Intracellular calcium $\left[\mathrm{Ca}^{++}\right]_{\mathrm{i}}$}

When cells were exposed to $10^{-6} \mathrm{M} T B T$, intracellular $\mathrm{Ca}^{++}$increased progressively compared with data obtained for the same cells before exposition to TBT. Results expressed in percentage of the control value for each cell became statistically different after 6 and 9 min of treatment (Fig. 6). A 14\% increase of intracellular $\mathrm{Ca}^{++}$measured after $9 \mathrm{~min}$.

\subsection{ATP level}

As illustrated in Figure 7, ${ }^{31} \mathrm{P}$ NMR spectra recorded for oyster hearts incubated ex vivo with TBT showed a trend towards a dose-dependent reduction of the ATP /ADP ratio compared with the control. The decrease of ATP rate, related to cell injury, was observed for $10^{-6} \mathrm{M}, 10^{-8} \mathrm{M}$ and $10^{-10} \mathrm{M}$ TBT after only $10 \mathrm{~min}$ of exposure.

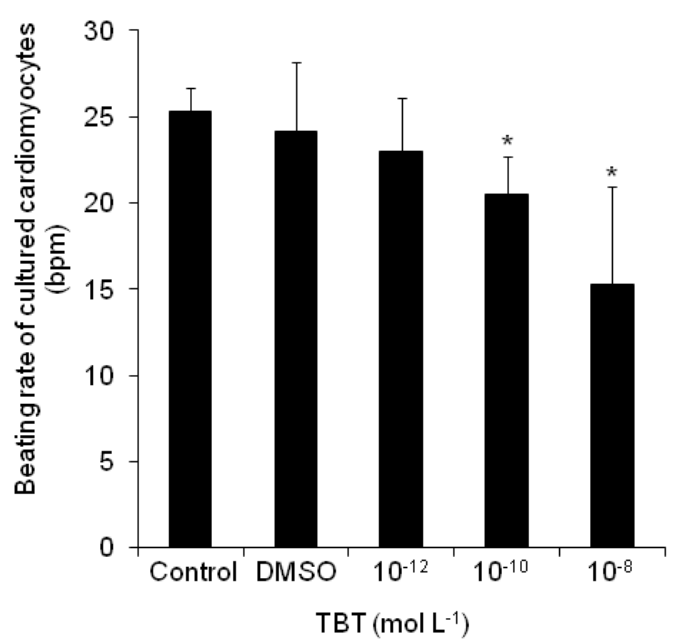

(a)

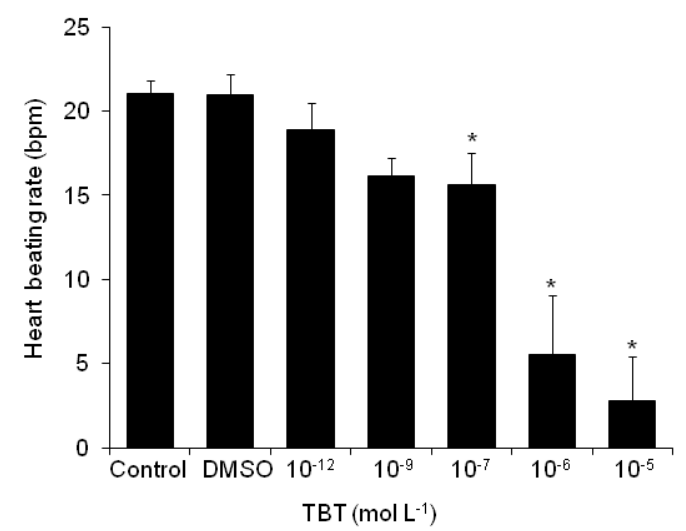

(b)

Fig. 5. Top: Spontaneous beating rate of cultured atrial cells after 6 days of TBT exposure $(n=6)$. Bottom: Oyster heart beating rate after 6 days of TBT exposure; * Means are significantly different $(p<0.05)$ from control $(n=4)$.

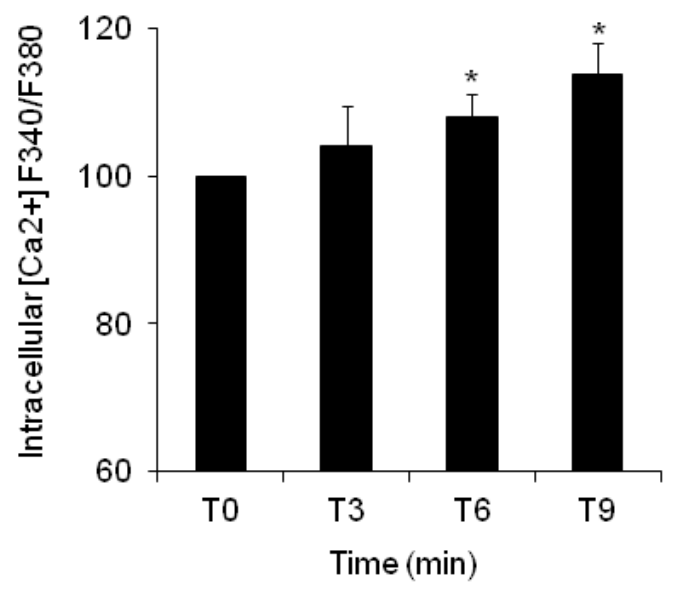

Fig. 6. $\left[\mathrm{Ca}^{2+}\right]_{\mathrm{i}}$ in cardiomyocytes exposed over $9 \min$ period to $T B T$ $10^{-6} \mathrm{M}$ - Fura 2AM test; *means are significantly different $(p<0.05)$ from control $(n=4)$. 


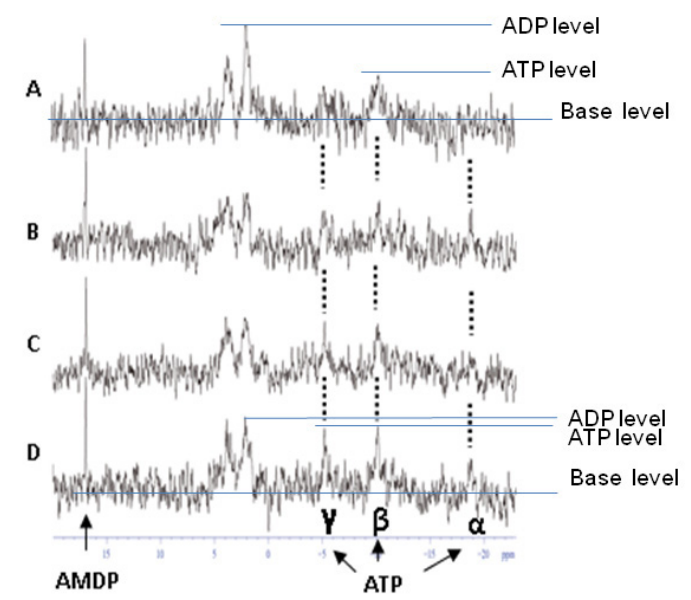

Fig. 7. Representative ${ }^{31} \mathrm{P}$ NMR spectra of oyster heart exposed ex vivo for 10 min to TBT. A: $10^{-6} \mathrm{M}$; B: $10^{-8} \mathrm{M}$; C: $10^{-10} \mathrm{M}$; D: control; AMDP: methylene di-phosphonate; ATP: adenosine tri-phosphate; ADP: adenosine di-phosphate.

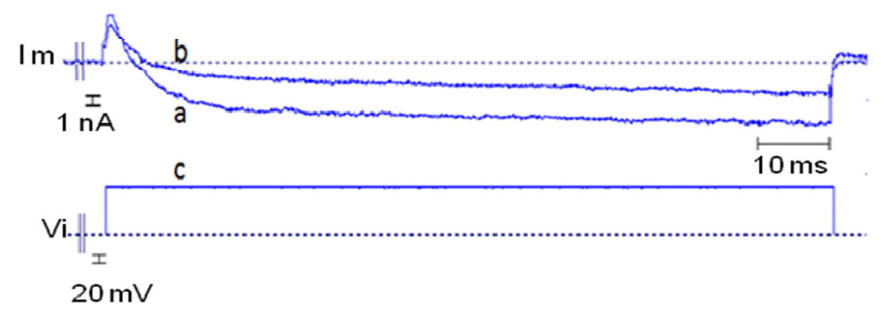

Fig. 8. Example of calcium current inhibition after $10 \mathrm{~min}$ of exposure to $10^{-9} \mathrm{M} T B T$. a: recording of the calcium current in control medium + TEA (tetraethylammonium; b: recording of the calcium current after addition of $T B T 10^{-9} \mathrm{M}$; c: imposed voltage from resting potential.

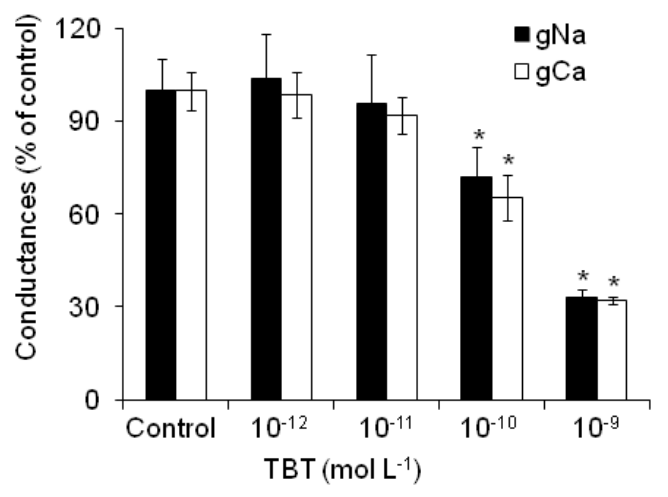

Fig. 9. Effect of $10 \mathrm{~min}$ of treatment with $T B T$ on the sodium and calcium conductance in cultured cardiomyocytes; *means are significantly different (Student $t$-test; $p<0.05$ ) from control.

\subsection{Electrophysiological studies}

In atrial cells exposed to $10^{-9} \mathrm{M} T B T$ for $10 \mathrm{~min}$, patch clamp measurements showed a reduction of ionic currents $\left(\mathrm{Ca}^{++}, \mathrm{Na}^{+}\right)$compared with controls for the same voltage steps imposed on the membrane (Figs. 8 and 9).
Table 1. Potassium channel conductance after $10 \mathrm{~min}$ exposure to TBT $10^{-6} \mathrm{~mol} \mathrm{~L}^{-1}(\mathrm{M}) . \mathrm{K}_{\mathrm{Ca}}$ channels were inhibited by clotrimazol $10^{-4} \mathrm{M}$ and $\mathrm{K}_{\text {ATP }}$ channels by glibenclamide $10^{-4} \mathrm{M}$; Macro-patch clamp; SD: Standard deviation, * indicates means significantly different $(p<0.05)$ from control $(n=6)$.

\begin{tabular}{cc}
\hline Conditions & $\begin{array}{c}\text { Conductance } \pm \text { SD } \\
(\mathrm{nA})\end{array}$ \\
\hline Control & $0.266 \pm 0.027$ \\
$T B T 10^{-6} \mathrm{~mol} \mathrm{~L}$ & $0.635 \pm 0.044$ \\
$T B T 10^{-6} \mathrm{~mol} \mathrm{~L}^{-1}+$ glibenclamide & $0.189 \pm 0.08$ \\
$T B T 10^{-6} \mathrm{~mol} \mathrm{~L}^{-1}+$ clotrimazol & $0.37 \pm 0.02$ \\
\hline
\end{tabular}

With a higher concentration of TBT $\left(10^{-6} \mathrm{M}\right)$, an increase of $\mathrm{K}^{+}$currents was observed. Indeed, a conductance (g) of $0.635 \mathrm{nA} \mathrm{mV}-1$ was detected in treated cells compared to $0.26 \mathrm{nA}^{-1}$ in the control (Table 1). Addition of glibenclamide or clotrimazol reduced these $\mathrm{K}^{+}$currents, confirming the involvement of ATP-dependent $\left(\mathrm{K}_{\text {ATP }}\right)$ and $\mathrm{Ca}^{++}$-dependent $\mathrm{K}^{+}$ channels $\left(\mathrm{K}_{\mathrm{Ca}}\right)$.

After treatment with clotrimazol, $\mathrm{K}_{\mathrm{ATP}}$ conductance

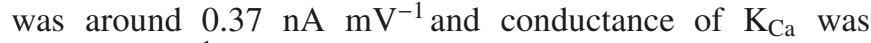
$0.19 \mathrm{nA} \mathrm{mV}^{-1}$ after glibenclamide addition. The increase of overall potassium channel conductance was attributed to an increase in both $\mathrm{K}_{\mathrm{ATP}}$ and $\mathrm{K}_{\mathrm{Ca}}$ conductance by $T B T$ treatment.

\section{Discussion}

Primary cultures of oyster cardiac cells were successfully developed in our laboratory and are now routinely obtained in a similar way to our successful cultures of scallop and clam heart cells (Le Marrec-Croq et al. 1998, 1999; Pennec et al. 2002, 2004; Droguet 2006; Hanana 2011; Hanana et al. 2011). An interesting point about these different species is that, in the natural environment, they are representative of different ecosystems where $T B T$ pollution may occur.

Interestingly, cardiac cell cultures can be established from cells freshly isolated from animals as well as from cryopreserved cells (Le Marrec-Croq et al. 1999), thus providing a constant standardized source of cells for in vitro cultures and applied research. These cultures are heterogeneous as they present three types of adherent cells: (i) round cells identified as haemocytes (ii) epithelial-like cells isolated from the external epithelium of the heart and (iii) spontaneously beating fibroblastic cells that are cardiomyocytes (Pennec et al. 2004; Talarmin et al. 2008).

Evaluation of the cardiomyocyte cell beating rate represents a fast and inexpensive method that could be used routinely in ecotoxicology to evaluate the potential cytotoxicity of chemicals. It is hoped that in the future this method could be automated. However, this approach cannot provide deep insights into the signalling pathways involved in the toxicity of compounds under investigation. Alternatively, the patch clamp technique can give valuable information about cellular toxicity mechanisms by evaluating the effect of chemicals on ionic channels. Alteration of ionic currents in cultured cardiomyocytes can be directly related to cardiac function and therefore to the viability of animals. 
The analytical methods used in the present study were carried out to evaluate in vitro the effects of TBT on the whole cell population (MTT assay, flow cytometry, YOPRO ${ }^{\circledR}-1, \mathrm{RMN}$ ). Other studies could be undertaken to investigate the proteins involved in detoxication processes or in the apoptosis mechanism: e.g., caspases or MAP kinases (Talarmin et al. 2008). Therefore, primary heart cell cultures can be used as bioassays for the study of the effects of natural or exogenous compounds found in the marine environment.

Other in vitro models from marine invertebrates have also been used in marine ecotoxicological studies: oyster embryos (Galgani et al. 2009; Mamindy-Pajany et al. 2011), sponge primmorphs (Châtel et al. 2011) and isolated invertebrate haemocytes (Anderson et al. 1997; Cima et al. 2004, 2008; Gopalakrishnan et al. 2011; Greco et al. 2011). In haemocytes, the study of pollutant effects demonstrated an alteration of parameters such as cell viability, phagocytotic activity, esterase activity or production of reactive oxygen species (Cima et al. 2004; Gagnaire et al. 2006; Gopalakrishnan et al. 2011). Experiments performed on hemocytes only allow a short exposure period ( $1 \mathrm{~h}$ to $24 \mathrm{~h}$ ) to a pollutant, while cultured heart cells can be used as bioassays over a longer period because cells remain viable and functional in vitro for up to one month (Pennec et al. 2004). This is of a major interest for the study of low level concentrations of pollutants and the determination of the NOEC (no observe effect concentration).

The deleterious effects of $T B T$ on marine bivalves have been widely reviewed (Alzieu 2000; Antizar-Ladislao 2008). For oysters, these include effects on reproduction, embryogenesis, larval growth, shell thickening, oxygen consumption, and adult survival, which can possibly lead to population decline.

The comparison of data from the literature is made difficult by the marked difference of organotin toxicity among taxonomic groups, the possibly related difference in sensitivity to $T B T$ with a higher sensitivity of females than males (Hagger et al. 2006; Horigushi et al. 2006), the age-dependent organotin toxicity (Roberts et al. 1987; Perina et al. 2011), and the effect of interactions between TBT concentration and water temperature and salinity (Antizar-Ladislao 2008). In laboratory studies, butyltin associated with oxide (TBTO) or chloride (TBTCl) is normally used for experiments (Antizar-Ladislao 2008). $T B T$ concentration in sediments, as reported for several regions in the world, reaches up to $14000 \mathrm{ng} \mathrm{g}^{-1} \mathrm{dw} \mathrm{Sn}$ (AntizarLadislao 2008). TBT is also known to be bioconcentrated in aquatic biota and to pass from phytoplankton to higher trophic levels, being rapidly absorbed and bio-concentrated in bacteria or algae, as well as in molluscs. A specific accumulation of organotin compounds in different tissues, particularly heart, was measured in Thais clavigera (Horiguchi et al. 2012). Results from the laboratory and studies in the marine environment showed that values of bioconcentration factors ranged from a few thousands to 220000 in molluscs (Tong et al. 1996). In oysters, Waldock and Tain (1983) reported TBTbioaccumulation factors of 2 300-11400 after 56 days of exposure. Roberts et al. (1987) indicated that an eight-week exposure of oysters to a mean concentration of $1 \mathrm{ng} \mathrm{L}^{-1} T B T$ (= $4 \times 10^{-12} \mathrm{M}$ ) resulted in a bioconcentration factor of 49000 .

Results obtained in the in vivo experiments of this study showed that $10^{-6} \mathrm{M} T B T$ chloride was not toxic for oysters after 3 days of exposure. However, after 6 days, only 35\% of animals survived and after 11 days, this concentration induced $100 \%$ mortality. Data from the literature reported $L C_{50}$ values for adult oysters, after 4 days of exposure, of $1.29 \times 10^{-6} \mathrm{M}$ TBT for Ostrea edulis and $2 \times 10^{-6} \mathrm{M}$ for Crassostrea gigas (Pickwell and Steinert 1988). For Mytilus edulis, the reported $L C_{50}$ is between $3.3 \times 10^{-7} \mathrm{M}$ and $10^{-6} \mathrm{M}$ after 4 days. Thus, our in vivo data are in agreement with published results on marine invertebrates. For in vitro experiments, the MTT assay allows the detection of a basal TBT toxicity related to a dysfunction of mitochondria. After 2 days of exposure to $10^{-6} \mathrm{M} T B T$, only $77 \%$ of cultured heart cells remained viable while $100 \%$ of oysters survived. In addition, beating rate of isolated cardiomyocytes was significantly decreased in vitro by $10^{-10} \mathrm{M}$ $T B T$ after 6 days, while the heart rate of oysters was only significantly reduced for $10^{-7} \mathrm{M} T B T$ after the same exposure time. According to the range of $T B T$ concentrations studied, the estimated NOEC was $10^{-12} \mathrm{M}$ TBT in vitro compared with $10^{-9} \mathrm{M} T B T$ for the in vivo experiments.

We can conclude that the in vitro bioassay was three orders of magnitude more sensitive than the whole oysters in short term experiments, and that isolated cells react to lower concentrations of TBT. Moreover, our results on heart primary cell cultures demonstrated dose- and time-dependent effects of $T B T$ on cell viability as in other cellular models (Hagger et al. 2005; Châtel et al. 2001; Hanana et al. 2011). The decrease in cultured heart cell viability could be explained by the induction of apoptosis and/or necrosis. The lipophilic nature of TBT makes it an active membrane toxicant (Ortiz et al. 2005). It was demonstrated using flow cytometry and YO-PRO ${ }^{\circledR}$ staining that around $10 \%$ of cells are apoptotic and necrotic after only 10 min of treatment with $10^{-6} \mathrm{M}$ TBT.

The apoptotic effect and its mechanisms have already been described in mammalian cell cultures (Aw et al. 1990; Raffray et al. 1993). Results obtained in similar experimental conditions are in accordance with our data. Moreover, a rapid timedependant increase in the number of apoptotic mammalian cells was observed during the first hour of incubation with $2 \times 10^{-6}$ M TBT (Stridh et al. 1999; Jurkiewicz et al. 2004; Nakatsu et al. 2007). Aluoch (2007) revealed that exposure to $3 \times 10^{-7} \mathrm{M}$ TBT for $10 \mathrm{~min}$ increased the activation of proapoptotic proteins.

Induction of apoptosis is correlated with an early and rapid decline of ATP level. Ex vivo, after 10 min incubation with $10^{-10} \mathrm{M}$ to $10^{-6} \mathrm{M} T B T$, we observed a dose-dependent decrease of the ATP level in the oyster hearts compared with controls. A significant decrease of intracellular ATP was also reported in the literature for other bioassays (Stridh et al. 1999; Whalen et al. 2000; Nakatsu et al. 2008).

After a short exposure $(10 \mathrm{~min})$ to $T B T 10^{-6} \mathrm{M}$, electrophysiological studies showed a rapid increase of outward current. This current was blocked by glibenclamide, a classical $\mathrm{K}_{\mathrm{ATP}}$ inhibitor. This $\mathrm{K}_{\mathrm{ATP}}$ current should be related to the decrease of ATP level in cardiomyocytes. In parallel, we observed a rapid increase of the intracellular $\mathrm{Ca}^{++}$concentration and a rapid increase of another $\mathrm{K}$ current, which was blocked by the known $\mathrm{K}_{\mathrm{Ca}}$ inhibitor clotrimazol. The opening of the potassium channels indicates cell suffering. Potassium channel activation shows there is cell damage and intracellular calcium 
increase. The increase in $\mathrm{K}_{\mathrm{Ca}}$ current was not related to an increase in the inward flux of $\mathrm{Ca}^{++}$. On the contrary, we observed a dose and time dependant reduction of the inward $\mathrm{Ca}^{++}$and $\mathrm{Na}^{+}$currents. Many previous reports have also demonstrated that $T B T$ increases intracellular $\mathrm{Ca}^{++}$concentration (Oyama et al. 1994; Mizuhashi et al. 2000; Nakatsu et al. 2006, 2007), which, in turn, can induce apoptosis (Chow et al. 1992; Corsini et al. 1997; Stridh et al. 1999). Apoptosis is related to mitochondrion dysfunction, demonstrated by the MTT assay, inducing ATP depletion and $\mathrm{Ca}^{++}$release. Hence, the origin of $\mathrm{Ca}^{++}$increase should be due to an intracellular release from the sarcoplasmic reticulum and to the inhibition of reticulum $\mathrm{Ca}^{++}$pumps (SERCA); this last effect is associated with the ATP depletion.

Finally, it was interesting to compare $T B T$ toxicity with the functionality of cardiomyocytes in vivo and in vitro: TBT decreased the beating rhythm of both in situ heart and isolated heart cells. Such a decrease can be related to the hyperpolarization of cardiomyocytes caused by the opening of large potassium channels $\left(\mathrm{K}_{\mathrm{Ca}}\right.$ and $\left.\mathrm{K}_{\mathrm{ATP}}\right)$ and a decrease of depolarizing calcium and sodium currents.

$T B T$ is known to alter cellular functions by different means, including transcriptional mechanisms (the reduction or alteration in DNA and protein synthesis, including ionic channel expression, apoptosis induction and post-transcriptional mechanisms) (Burgeot et al. 1995; Hagger et al. 2005), alteration of respiratory and ATP synthesis (Cameron et al. 1991), reduction of the $\mathrm{Na}^{+} / \mathrm{K}^{+}$pump activity (Pinkney et al. 1989), inhibition of SERCA pumps responsible for the transport of $\mathrm{Ca}^{++}$to the sarcoplasmic reticulum (Kodavanti et al. 1991; Hagger et al. 2005), inhibition of AMPc phosphorylation and decrease of catecholamine receptor affinity (Cameron et al. 1991).

\section{Conclusion}

Studies undertaken both in vivo and in vitro to estimate the suitability of primary cell cultures established from oyster heart for the assessment of toxicity of xenobiotics, show that the toxic effects evaluated in vitro and in vivo are consistent, with better sensitivity found in cultured cells. This novel approach would, therefore, allow the demonstration of toxic effects on cultured cells at low concentrations that appear innocuous in whole animals. The present work demonstrates that oyster heart cell cultures could be an alternative bioassay for the monitoring of various exogenous chemicals such as TBT in the marine environment. This alternative model follows REACH (Registration, Evaluation and Authorization of Chemicals) recommendations and could complement the currently used in vivo or in vitro models in marine ecotoxicology. Moreover, this model provides better insight into the mechanisms potentially involved in chemical toxicity as depicted in Figure 10 for TBT toxicity. The effect of TBT on ionic conductances, cytoplasmic $\mathrm{Ca}^{++}$, ATP level and apoptosis has been observed in the present study. These data, in agreement with literature, can explain the decrease of heart beating rhythm, and the eventual death of cells and consequently of animals. The high sensitivity of oyster heart cell cultures to TBT, combined with the good consistency of in vivo and in vitro studies,

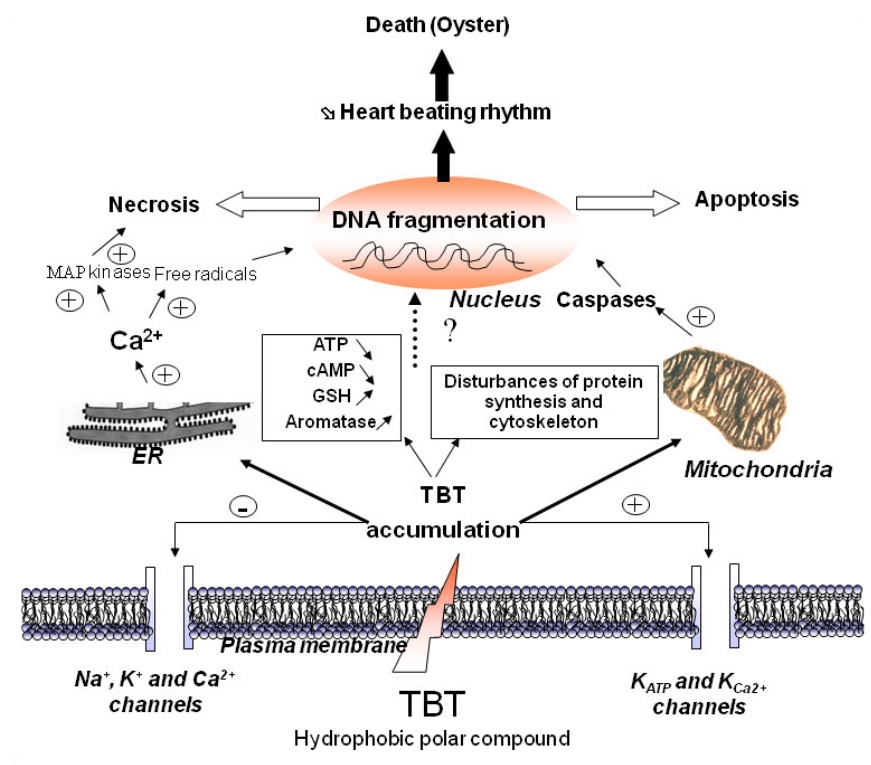

Fig. 10. A proposed model of the pathway involved in acute $T B T$ toxicity in oyster atrial cells.

strongly corroborates the potential of using these cells as an innovative biological tool for eco-toxicological research.

Acknowledgements. This work was supported by grants from the European Commission - Thematic programme: Environment and sustainable development

\section{References}

Almers W., Stanfield P.R., Stühmer W., 1983, Lateral distribution of sodium and potassium channels in frog skeletal muscle: measurements with a patch clamp technique. J. Physiol. 336, 261-284.

Aluoch A., Odman-Ghazi S., Whalen M., 2007, Pattern of MAP kinases p44/42 and JNK activation by non-lethal doses of tributyltin in human natural killer cells. Arch. Toxicol. 81, 271-277.

Alzieu C., Michel P., Tolosa I., Bacci E., Mee L.D., Readman J.W., 1991, Organotin coumpounds in the Mediterranean: a continuing cause for concern. Mar. Environ. Res. 32, 261-270.

Alzieu C., 2000, Environmental impact of TBT: the French experience. Sci. Tot. Environ. 258, 99-102.

Anderson R.S., Unger M.A., Burreson E.M., 1996, Enhancement of Perkinsus marinus disease progression in TBT-exposed oysters (Crassostrea virginica). Mar. Environ. Res. 42, 177-180.

Anderson R.S., Brubacher L.L., Burreson E.M., Unger M.A., 1997, Effects of in vitro exposure to tributyltin on generation of oxygen metabolites by oyster hemocytes. Environ. Res. 74, 84-90.

Antizar-Ladislao B., 2008, Environmental levels, toxicity and human exposure to tributyltin (TBT)-contaminated marine environment. Environ. Intl. 34, 292-308.

Aw T.Y., Nicotera P., Manzo L., Orrenius S., 1990, Tributyltin stimulates apoptosis in rat thymocytes. Arch. Biochem. Biophys. 283, 46-50.

Berto D., Giani M., Boscolo R., Covelli S., Giovanardi O., Massironi M., Grassia L., 2007, Organotins (TBT and DBT) in water, sediments, and gastropods of the southern Venice lagoon (Italy). Mar. Pollut. Bull. 55, 425-435. 
Bhosle N.B., Garg A., Jadhav S., Harjee R., Sawant S.S., Venkat K., Anil A.C., 2004, Butyltins in water, biofilm, animals and sediments of the west coast of India. Chemosphere 57, 897-907.

Burgeot T., His E., Galgani F., 1995, The micronucleus assay in Crassostrea gigas for the detection of seawater genotoxicity. Mutat. Res. 342, 125-140.

Burton E.D., Phillips I.R., Hawker D.W., 2004, Sorption and desorption behavior of tributyltin with natural sediments. Environ. Sci. Technol. 38, 6694-6700.

Cameron J.A., Kodavanti P.R., Pentyala S.N., Desaiah D., 1991, Triorganotin inhibition of rat cardiac adenosine triphosphatases and catecholamine binding. J. Appl. Toxicol. 11, 403-409.

Châtel A., Talarmin H., Hamer B., Schröder H.C., Müller W.E., Dorange G., 2011, MAP kinase cell signaling pathway as biomarker of environmental pollution in the sponge Suberites domuncula. Ecotoxicology 20, 1727-1740.

Chow S.C., Kass G.E., McCabe Jr., M.J., Orrenius S., 1992, Tributyltin increases cytosolic free $\mathrm{Ca}^{2+}$ concentration in thymocytes by mobilizing intracellular $\mathrm{Ca}^{2+}$, activating a $\mathrm{Ca}^{2+}$ entry pathway, and inhibiting $\mathrm{Ca}^{2+}$ efflux. Arch. Biochem. Biophys. 298, 143-149.

Cima F., Ballarin L., 2004, Tributyltin-sulfhydryl interaction as a cause of immunotoxicity in phagocytes of tunicates. Ecotoxicol. Environ. Saf. 58, 386-395.

Cima F., Bragadin M., Ballarin L., 2008, Toxic effects of new antifouling compounds on tunicate haemocytes I. Sea-nine 211 and chlorothalonil. Aquat Toxicol. 86, 299-312.

Corsini E., Viviani B., Marinovich M., Galli C.L., 1997, Role of mitochondria and calcium ions in tributyltin-induced gene regulatory pathways. Toxicol. Appl. Pharmacol. 145, 74-81.

Domart-Coulon I., Auzoux-Bordenave S., Doumenc D., Khalanski M., 2000, Cytotoxicity assessment of antibiofouling compounds and by-products in marine bivalve cell cultures. Toxicol. in vitro $14,245-251$.

Dong W., Muramoto W., Nagai Y., Takehana K., Stegeman J.J., Teraoka H., Hiraga T., 2006, Retinal neuronal cell is a toxicological target of tributyltin in developing zebrafish. J. Vet. Med. Sci. 68, 573-579.

Dowson P.H., Bubb J.M., Lester J.N., 1993, Temporal distribution of organotins in the aquatic environment: five years after the 1987 UK retail began on TBT-base antifouling paints. Mar. Pollut. Bull. 26, 487-494.

Droguet M., 2006, Étude des caractéristiques fonctionnelles de cardiomyocytes d'huître en culture. UFR Médecine et Sciences de la Santé, Université de Bretagne Occidentale, Brest, Ph.D.

Gagnaire B., Thomas-Guyon H., Burgeot T., Renault T., 2006, Pollutant effects on Pacific oyster, Crassostrea gigas (Thunberg), hemocytes: screening of 23 molecules using flow cytometry. Cell. Biol. Toxicol. 22, 1-14.

Gagné F., Blaise C., Pellerin J., Pelletier E., Douville M., GauthierClerc S., Viglino L., 2003, Sex alteration in soft-shell clams (Mya arenaria) in an intertidal zone of the Saint Lawrence river (Quebec, Canada). Comp. Biochem. Physiol. C. Toxicol. Pharmacol. 134, 189-198.

Galgani F., Senia J., Guillou J.L., Laugier T., Munaron D., Andral B., Guillaume B., Coulet E., Boissery P., Brun L., Bertrandy M.C., 2009, Assessment of the environmental quality of French continental Mediterranean lagoons with oyster embryo bioassay. Arch. Environ. Contam. Toxicol. 57, 540-451.
Gopalakrishnan S., Huang W.B., Wang Q.W., Wu M.L., Liu J., Wang K.J., 2011, Effects of tributyltin and benzo[a]pyrene on the immune-associated activities of hemocytes and recovery responses in the gastropod abalone, Haliotis diversicolor. Comp. Biochem. Physiol. C. Toxicol. Pharmacol. 154, 120-128.

Greco L., Pellerin J., Capri E., Garnerot F., Louis S., Fournier M., Sacchi A., Fusi M., Lapointe D., Couture P., 2011, Physiological effects of temperature and a herbicide mixture on the softshell clam Mya arenaria (Mollusca, Bivalvia). Environ. Toxicol. Chem. 30, 132-141.

Grynkiewicz G., Poenie M., Tsien R.Y., 1985, A new generation of $\mathrm{Ca}^{2+}$ indicators with greatly improved fluorescence properties. J. Biol. Chem. 260, 3440-3450.

Hagger J.A., Depledge M.H., Galloway T.S., 2005, Toxicity of tributyltin in the marine mollusc Mytilus edulis. Mar. Pollut. Bull. 51, 816-826.

Hagger J.A., Depledge M.H., Oehlmann J., Jobling S., Galloway T.S., 2006, Is there a causal association between genotoxicity and the imposex effect? Environ. Health Perspect. 114, 20-26.

Hanana H., 2011, Etablissement de primocultures de cellules cardiaques de palourde Ruditapes decussatus - Étude des courants ioniques et des MAP kinases après exposition des cellules à des xénobiotiques. UFR Médecine et Sciences de la Santé. Université de Bretagne Occidentale, Brest, Ph.D.

Hanana H., Talarmin H., Pennec J.P., Droguet M., Gobin E., Marcorelle P., Dorange G., 2011, Establishment of functional primary cultures of heart cells from the clam Ruditapes decussatus. Cytotechnology 63, 295-305.

Horiguchi T., 2006, Masculinization of female gastropod mollusks induced by organotin compounds, focusing on mechanism of actions of tributyltin and triphenyltin for development of imposex. Environ. Sci. 13, 77-87.

Horiguchi T., Kojima M., Hamada F., Kajikawa A., Shiraishi H., Morita M., Shimizu M., 2006, Impact of tributyltin and triphenyltin on ivory shell (Babylonia japonica) populations. Environ. Health Perspect. 114 (Suppl. 1), 13-19.

Horiguchi T., Lee J.H., Park J.C., Cho H.S., Shiraishi H., Morita M., 2012, Specific accumulation of organotin compounds in tissues of the rock shell, Thais clavigera. Mar. Environ. Res. 76, 56-62.

Idziorek T., Estaquier J., De Bels F., Ameisen J.C., 1995, YOPRO1 permits cytofluorometric analysis of programmed cell death (apoptosis) without interfering with cell viability. J. Immunol. Meth. 185, 249-258

Inoue S., Oshima Y., Nagai K., Yamamoto T., Go J., Kai N., Honjo T., 2004, Effect of maternal exposure to tributyltin on reproduction of the pearl oyster (Pinctada fucata martensii). Environ. Toxicol. Chem. 23, 1276-1281.

Inoue S., Abe S., Oshima Y., Kai N., Honjo T., 2006a, Tributyltin contamination of bivalves in coastal areas around northern Kyushu, Japan. Environ. Toxicol. 21, 244-249.

Inoue S., Oshima Y., Usuki H., Hamaguchi M., Hanamura Y., Kai N., Shimasaki Y, Honjo T., 2006b, Effects of tributyltin maternal and/or waterborne exposure on the embryonic development of the Manila clam, Ruditapes philippinarum. Chemosphere 63, 881-888.

Inoue S., Oshima Y., Usuki H., Hamaguchi M., Hanamura Y., Kai N., Shimasaki Y., Honjo T., 2007, Effect of tributyltin on veliger larvae of the Manila clam, Ruditapes philippinarum. Chemosphere 66, 1353-1357. 
Janer G., Lyssimachou A., Bachmann J., Oehlmann J., SchulteOehlmann U., Porte C., 2006, Sexual dimorphism in esterified steroid levels in the gastropod Marisa cornuarietis: the effect of xenoandrogenic compounds. Steroids 71, 435-444.

Jurkiewicz M., Averill-Bates D.A., Marion M., Denizeau F., 2004, Involvement of mitochondrial and death receptor pathways in tributyltin-induced apoptosis in rat hepatocytes. Biochim. Biophys. Acta 1693, 15-27.

Kodavanti P.R., Cameron J.A., Yallapragada P.R., Vig P.J., Desaiah D., 1991, Inhibition of $\mathrm{Ca}^{2+}$ transport associated with cAMPdependent protein phosphorylation in rat cardiac sarcoplasmic reticulum by triorganotins. Arch. Toxicol. 65, 311-317.

Le Deuff R.M., Lipart C., Renaud R., 1994, Primary culture of Pacific oyster, Crassostrea gigas, heart cells. J. Tissue Cult. Meth. 16, 67-72.

Le Marrec-Croq F., Fritayre P., Chesné C., Guilouzo A., Dorange G., 1998, Cryopreservation of Pecten maximus heart cells. Cryobiology 37, 200-206.

Le Marrec-Croq F., Glaise D., Guguen-Guillouzo C., Chesne C., Guillouzo A., Boulo V., Dorange G., 1999, Primary cultures of heart cells from the scallop Pecten maximus (Mollusca-Bivalvia). In Vitro Cell. Dev. Biol. Anim. 35, 289-295.

Mamindy-Pajany Y., Hamer B., Romeo M., Geret F., Galgani F., Durmisi E., Hurel C., Marmier N., 2011, The toxicity of composted sediments from Mediterranean ports evaluated by several bioassays. Chemosphere 82, 362-369.

Mizuhashi S., Ikegaya Y., Matsuki N., 2000, Cytotoxicity of tributyltin in rat hippocampal slice cultures. Neurosci. Res. 38, $35-42$.

Mosman T., 1983, Rapid colorimetric assay for cellular growth and survivals: Application to proliferation and cytotoxicity assays. J. Immunol. Meth. 65, 55-63.

Nakatsu Y., Kotake Y., Ohta S., 2006, Tributyltin-induced cell death is mediated by calpain in PC12 cells. Neurotoxicology 27, 587-593.

Nakatsu Y., Kotake Y., Ohta S., 2007, Concentration dependence of the mechanisms of tributyltin-induced apoptosis. Toxicol. Sci. 97, 438-447.

Nakatsu Y., Kotake Y., Hino A., Ohta S., 2008, Activation of AMPactivated protein kinase by tributyltin induces neuronal cell death. Toxicol. Appl. Pharmacol. 230, 358-363.

Ohji M., Arai T., Miyazaki N., 2005, Acute toxicity of tributyltin to the Caprellidea (Crustacea: Amphipoda). Mar. Environ. Res. 59, 197-201.

Ortiz A., Teruel J.A., Aranda F.J., 2005, Effect of triorganotin compounds on membrane permeability. Biochim. Biophys. Acta $1420,137-142$.

OSPAR-Convention, 2004, Provisional JAMP Assessment Criteria for TBT - Specific Biological Effects. r. 004-15.

Oyama Y., Ueha T., Hayashi A., Chikahisa L., 1994, Effect of tri-nbutyltin on intracellular $\mathrm{Ca}^{2+}$ concentration of mouse thymocytes under $\mathrm{Ca}\left({ }^{2+}\right)$-free condition. Eur. J. Pharmacol. 270, 137-142.

Pelletier E., Sargian P., Payet J., Demers S., 2006, Ecotoxicological effects of combined UVB and organic contaminants in coastal waters: A review. Photochem. Photobiol. 82, 981-993.
Pennec J.P., Gallet M., Gioux M., Dorange G., 2002, Cell culture of bivalves: tool for the study of the effects of environmental stressors. Cell. Mol. Biol. 48, 351-358.

Pennec J.P., Talarmin H., Droguet M., Giroux-Metges M.A., Gioux M., Dorange G., 2004, Characterization of the voltage-activated currents in cultured atrial myocytes isolated from the heart of the common oyster Crassostrea gigas. J. Exp. Biol. 207, 3935-3944.

Perina F.C., Abessa D.M., Pinho G.L., Fillmann G., 2011, Comparative toxicity of antifouling compounds on the development of sea urchin. Ecotoxycology 20, 1870-1880.

Pickwell G.V., Steinert S.A., 1988, Accumulation and effects of organotin compounds in oysters and mussels: correlation with serum biochemical and cytological factors and tissue burdens. Mar. Environ. Res. 24, 215-218.

Pinkney A.E., Wright D.A., Jepson M.A., Towle D.W., 1989, Effects of tributyltin compounds on ionic regulation and gill ATPase activity in estuarine fish. Comp. Biochem. Physiol. C, 92, 125-129.

Raffray M., Cohen G.M., 1993, Thymocyte apoptosis as a mechanism for tributyltin-induced thymic atrophy in vivo. Arch. Toxicol. 67, 231-236.

Roberts M.H., 1987, Acute toxicity of tributyltin chloride to embryos and larvae of two bivalve molluscs, Crassostrea virginica and Mercenaria mercenaria. Bull. Environ. Contam. Toxicol. 39, 1012-1019.

Stridh H., Fava E., Single B., Nicotera P., Orrenius S., Leist M., 1999, Tributyltin-induced apoptosis requires glycolytic adenosine trisphosphate production. Chem. Res. Toxicol. 12, 874-882.

Talarmin H., and Droguet M., Pennec J.P., Schröder H.C., Müller W.E.G, Dorange G., 2008, Effects of a phycotoxin, the okadaïc acid, on oyster heart cell survival. Toxicol. Environ. Chem. 90, 153-168.

Tong S.L., Pang F.Y., Phang S.M., Lai H.C., 1996, Tributyltin distribution in the coastal environment of Peninsular Malaysia. Environ. Pollut. 91, 209-216.

Tsunoda M., Aizawa Y., Konno N., Kimura K., Sugita-Konishi Y., 2006, Subacute administration of tributyltin chloride modulates neurotransmitters and their metabolites in discrete brain regions of maternal mice and their F1 offspring. Toxicol. Indust. Health $22,15-25$.

Unger M.A., MacIntyre W.G., Huggett R.J., 1988, Sorption behavior of tributyltin on estuarine and freshwater sediments. Environ. Toxicol. Chem. 7, 907-915.

Viglino L., Pelletier E., 2006, Butylétains dans les eaux du fjord du Saguenay (Canada) : menace pour l'écosystème d'un milieu semi-fermé ? Rev. Sci. Eau 19, 11-22.

Waldock M.J., Thain J.E., 1983, Shell thickening in Crassostrea gigas: organotin antifouling or sediment induced. Mar. Pollut. Bull. 14, 411-415.

Whalen M.M., Loganathan B.G., Yamashita N., 2000, Effect of in vitro exposure to selected endocrine disrupting chemicals on human natural killer (NK) cell function. Organohalogen Comp. 49, 259-261.

Zhang J., Zuo Z., Wang Y., Yu A., Chen Y., Wang C., 2011, Tributyltin chloride results in dorsal curvature in embryo development of Sebastiscus marmoratus via apoptosis pathway. Chemosphere 82, 437-442. 